\title{
Correlation of perfusion index with patent ductus arteriosus repercussion in premature newborns
}

\section{Correlación del índice de perfusión con la repercusión del conducto arterioso permeable en recién nacidos prematuros}

\author{
Eduardo A. Navarro-Guzmán ${ }^{1}$, Iván Ledezma-Bautista², Martha E. Rubio-Hernández, \\ Francisco J. Escalante-Padrón ${ }^{1}$, Victoria Lima-Roguel, and Mauricio Pierdant-Perez ${ }^{1 *}$ \\ ${ }^{1}$ Department of Neonatology, Hospital Central Dr. Ignacio Morones Prieto; ${ }^{2}$ Department of Clinical Epidemiology, Faculty of Medicine, Universidad \\ Autónoma de San Luis Potosí; ${ }^{3}$ Department of Pediatrics, Hospital Central Dr. Ignacio Morones Prieto, San Luis Potosí, Mexico
}

\begin{abstract}
Background: The ductus arteriosus is a necessary structure in fetal circulation, and its patency can produce hemodynamic alterations. The diagnostic gold standard is echocardiography, not always available. In the neonatal intensive care unit (NICU), they have pulse oximetry that measures perfusion index (PI), which could be used as a diagnostic tool in hemodynamically significant patent ductus arteriosus (HSPDA). Objective: The objective of the study was to correlate the PI increment ( $\triangle P I)$ in 24 and $72 \mathrm{~h}$ after birth with HSPDA in premature newborns of NICU in a second-level hospital. Materials and methods: This is an analytic prospective study which included neonates of 26-34 weeks of gestational age, without comorbidities, who underwent echocardiography and measurement of PI in arm and leg, 24 and $72 \mathrm{~h}$ after birth. We did bivariate analysis with X2/ exact Fisher's test and Student's t-test/Mann-Whitney U-test, besides Spearman correlation and linear regression for value prediction. Results: We included 39 premature newborns. We did not find significant differences between patients without and with HSPDA (median: 0.22 [0.06-0.58] vs. 0.03 [-0.27-0.2]; $p=0.09$ ) at 24 h neither $72 \mathrm{~h}$ after birth (median: 0.2 [0-0.47] vs. 0.45 [-0.37-0.76]; $p=0.47)$. We found a positive correlation between ductus arteriosus diameter (DAD) and $\triangle P I(r: 0.78$; confidence interval 95\%: 0.6-0.88; $p=0.01$ ). The prediction formula with linear regression is expressed this way: $D A D=1.31$ $+(2.05 \times \Delta I P)$. Conclusions: The PI does not allow us to discriminate between patient without and with HSPDA. The $\triangle P I$ could be a tool for the monitorization of DAD in neonates $72 \mathrm{~h}$ after birth.
\end{abstract}

Key words: Patent ductus arteriosus. Echocardiography. Infant. Newborn. Perfusion index. Mexico.

\section{Resumen}

Antecedentes: El conducto arterioso es una estructura necesaria en la circulación fetal, su persistencia puede provocar alteraciones hemodinámicas. El estándar de oro diagnóstico es la ecocardiografía, no siempre disponible. Las unidades de cuidados intensivos neonatales (UCIN) cuentan con oximetría de pulso, que mide el índice de perfusión (IP), el cual podría funcionar como auxiliar en el diagnóstico de persistencia del conducto arterioso hemodinámicamente significativo (PCAHs).

\section{Correspondence:}

*Mauricio Pierdant-Perez

Av. Venustiano Carranza, 2405

Col. Los Filtros

Date of reception: 13-09-2018

Date of acceptance: 24-10-2018

C.P. 78210, San Luis Potosi, Mexico

E-mail: mauricio.pierdant@uasIp.mx

DOI: 10.24875/ACME.M19000033
Available online: $30-10-2019$ Arch Cardiol Mex (Eng). 2019;89(2):111-117 www.archivoscardiologia.com 2604-7063 @ 2018 Instituto Nacional de Cardiología Ignacio Chávez. Published by Permanyer México SA de CV. This is an open access article under the CC BY-NC-ND license (http://creativecommons.org/licenses/by-nc-nd/4.0/). 
Objetivo: Correlacionar el incremento del índice de perfusión $(\Delta I P)$ a las 24 y 72 h de vida extrauterina con PCAHs en recién nacidos prematuros de la UCIN de un hospital de segundo nivel. Materials y métodos: Estudio de cohorte analítico prospectivo donde se incluyeron neonatos de 26 a 34 semanas de gestación, sin comorbilidades, a quienes se les realizó ecocardiograma y medición de IP en brazo y pierna a las 24 y $72 \mathrm{~h}$. Se efectuó análisis bivariante con Y2/prueba exacta de Fisher y $t$ de Student/U de Mann-Whitney, además correlación de Spearman y regresión lineal para predicción de valores. Resultados: Se incluyeron 39 prematuros. No se encontró diferencia significativa entre los pacientes sin y con PCAHs (mediana: $0.22[0.06,0.58]$ vs. $0.03[-0.27,0.2] ; p=0.09$ ) a las $24 h$ de vida y tampoco a las $72 h$ de vida (mediana: 0.2 [0, $0.47]$ vs. $0.45[-0.37,0.76], p=0.47)$. Se encontró una correlación positiva entre el diámetro del conducto arterioso (DCA) y el $\Delta I P(r: 0.78 ;$ IC 95\%: 0.60-0.88; $p=0.01)$. La fórmula de predicción por regresión lineal se expresa así: $D C A=1.31+$ $(2.05 x \Delta I P)$. Conclusiones: EI IP no permite discriminar entre pacientes sin y con PCAHs. El $\triangle I P$ podría ser una herramienta para la monitorización del diámetro del conducto en neonatos después de las 72 h de vida.

Palabras clave: Conducto arterioso permeable. Ecocardiografía. Recién nacido prematuro. Índice de perfusión. Méxicoc

\section{Introduction}

The incidence of patent ductus arteriosus (PDA) in preterm newborns is increased, especially in those weighing $<1000 \mathrm{~g}(59 \%)$ or with $<30$ weeks of gestation $(52 \%)^{1-6}$.

Transthoracic echocardiography is the gold standard for diagnosis. The impact on tissue oxygenation will depend on its hemodynamic significance. In 2009, Sehgal et al. defined hemodynamically significant patent ductus arteriosus (HSPDA) by means of specific echocardiographic criteria ${ }^{7,8}$. The large variability of hemodynamic impact of the duct throughout time makes it necessary for the circulatory state of the newborn to be continuously monitored, especially in premature neonates.

The perfusion index $(\mathrm{PI})$, which is defined as the ratio of the pulsatile and non-pulsatile components of blood flow in peripheral tissue, is measured with pulse oximetry and represents the "strength" of arterial pulse. It has been proposed as an indirect and non-invasive parameter, useful for patient assessment in different situations, especially related to the hemodynamic state, mainly sepsis or shock ${ }^{9-12}$.

Under the premise that with PDA, there is a "steal" of blood studies which have been carried out trying to demonstrate that $\mathrm{PI}$ increase $(\Delta \mathrm{PI})$, i.e., pre-ductal $\mathrm{PI}$ minus post-ductal $\mathrm{PI}$, is increased in patients with HSPDA.

In 2013, Vidal et al. determined that the measurement of a single PI (post-ductal) was not enough to differentiate patients with and without HSPDA ${ }^{13}$; however, on the same year, Khositseth et al., in Thailand, and with a sample of 30 neonates, found that $\Delta \mathrm{PI}$ was increased. By setting a $\Delta \mathrm{PI}$ cutoff point $>1.05$, they established a sensitivity (S) of $67 \%$, specificity (Sp) of $100 \%$, a positive predictive value (PPV) of $100 \%$, and a negative predictive value (NPV) of $86 \%{ }^{14}$. Three years later, Balla et al., in India, found the same difference and determined, with a sample of 27 patients (10 without and 17 with HSPCA), at day 1 , with a $\triangle \mathrm{PI}$ cutoff point $>0.85: \mathrm{S}=80 \%, \mathrm{Sp}=$ $94 \%, \mathrm{PPV}=88.9 \%$, and NPV $=88.9 \%$, with a positive likelihood ratio (PLR) of 13.33. For day 3 of life, and with a $\Delta \mathrm{PI}$ cutoff point $>0.95$, similar sensitivity values, $\mathrm{Sp}=$ $88.2 \%, \mathrm{PPV}=80 \%$, and NPV $=88.2 \%$, were found, as well as a PLR $=6.78^{14}$.

No studies have been carried out validating these results for routine use of this type of monitoring in the neonatal intensive care unit (NICU) for PDA screening in preterm newborns. The purpose of our study was to compare the $\Delta \mathrm{PI}$ values, measured with pulse oximetry, with PDA diagnosed by transthoracic echocardiography at 24 and $72 \mathrm{~h}$ of extrauterine life in preterm newborns.

\section{Materials and methods}

\section{Population}

From July 2017 to June 2018, 43 preterm infants who were admitted to the NICU of the Dr. Ignacio Morones Prieto Central Hospital were recruited. Not including one patient who had a hypoplastic left ventricle was decided, and two patients in whom performing echocardiography or PI measurement was not possible were eliminated, in addition to not including a patient who had severe early sepsis ${ }^{12}$, whose mother had a history of chorioamnionitis, with a total of 39 neonates being left for analysis. The neonates' gestational age, calculated using Capurro or Ballard method, as appropriate, ranged from 26 to 34.2 weeks of gestation (median: 30.5; mean: $30.5 \pm 2.4$ weeks), and weight ranged from 0.66 to $1.8 \mathrm{~kg}$ (median: 1.1; mean: $1.14 \pm 0.3 \mathrm{~kg}$ ).

Transthoracic echocardiography and simultaneous pre- and post-ductal PI measurements were performed, twice, at 24 and $72 \mathrm{~h}$ of extrauterine life after informed consent was granted by the neonate's parents or legal 


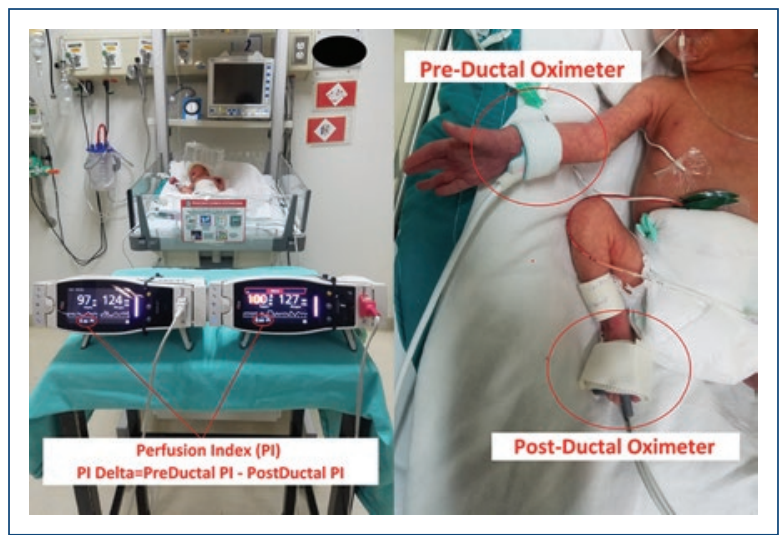

Figure 1. Photograph of the procedure to measure the perfusion index and its increase.

$\mathrm{PI}$ : perfusion index; pre-ductal: sensor placed before ductus arteriosus anatomical presence, i.e., right arm; post-ductal: sensor placed after ductus arteriosus anatomical presence, i.e., right foot.

guardians. For sample size calculation, the 2013 Thai study by Khositseth was taken as the basis, with at least eight patients being required per group (with and without PDA), with a significance $(\alpha)$ of 0.05 and a power $(\beta)$ of 0.8 for the difference to be proven. HSPDA was defined, according to Sehgal et al., as any of the following findings: (a) transductal diameter $>1.5 \mathrm{~mm}$, (b) left atrium/aortic valve ratio $>1.4: 1$, or (c) retrograde diastolic flow in the descending aorta $>30 \%$.

\section{Devices and variables}

All echocardiograms were transthoracically performed by a single pediatric cardiologist, with an intraobserver intraclass correlation coefficient of 0.92 (95\% confidence interval [Cl]: 0.88-0.95), using a SonoSite ${ }^{\circledR}$ TITAN $^{\text {TM }}$ portable color Doppler ultrasound scanner, with the diameter of the left atrium, the aortic root, the left atrium: aortic valve ratio, and the descending aorta flow being measured, as well as the ductus arteriosus diameter (DAD) in case of patency.

For the PI measurement, the Masimo SET ${ }^{\circledR}$ Radical-7 rainbow pulse oximeter was used, with the readings being recorded by a single observer (ILB), in the neonatal mode, and echocardiography simultaneously being measured. Two independent oximeters were used to measure pre-ductal PI (by means of a sensor attached to the right wrist/hand) and post-ductal PI (sensor attached to the right ankle/foot), for 10 continuous minutes, with measurements being recorded every 20 $\mathrm{s}$, and an average of the 30 data obtained in that period

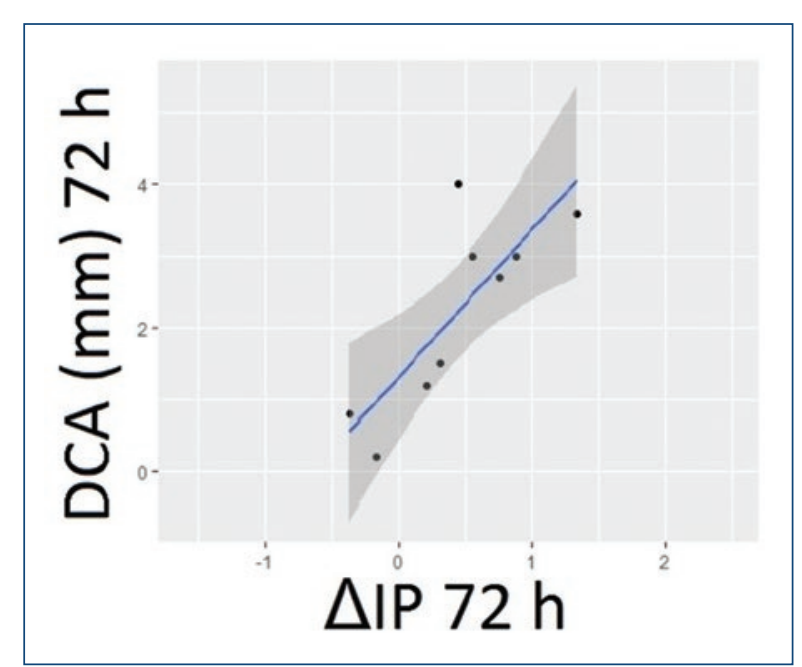

Figure 2. Scatter plot with regression line ( $r$ : 0.78; 95\% confidence interval: $0.60-0.88 ; p=0.01$ ).

DAD: ductus arteriosus diameter at $72 \mathrm{~h}$ of life; $\triangle \mathrm{PI}$ : perfusion index increase at $72 \mathrm{~h}$ of life.

being calculated. We defined $\Delta \mathrm{PI}$ as pre-ductal $\mathrm{PI}$ minus post-ductal PI (Fig. 1). The other variables were obtained as usual by neonatologists and nurses, just as recorded in the neonatology area medical records ${ }^{15}$.

\section{Statistical analysis}

The R Studio ${ }^{\circledR} 3.5$ program was used. Continuous variables were tested for normality with the Shapiro-Wilk test, as appropriate, and were expressed as means \pm standard deviations or medians (interquartile ranges). Categorical variables were expressed as absolute values and percentages. Student's t-test or Mann-Whitney's U-test was used for continuous variables and the Chisquare test or Fisher's exact test was used for categorical variables. In addition, correlations were made for continuous variables using Spearman's rho method, and for correlations, where statistical significance was found, linear regression was used for the prediction of values.

\section{Results}

Of the 39 analyzed patients, 22 belonged to the male gender $(56.4 \%)$ and 17 to the female gender $(43.6 \%)$. Fourteen patients $(35.9 \%)$ were diagnosed with PDA within the first $24 \mathrm{~h}$, two of them without hemodynamic significance, while only in $9(23 \%)$, it persisted at $72 \mathrm{~h}$, in seven of them with hemodynamic significance. None of the neonates had opening of a previously closed ductus. Table 1 shows patient clinical and hemodynamic 
Table 1. Descriptive statistics of our sample

\begin{tabular}{|c|c|c|c|c|}
\hline Variable & $\mathbf{n}=39(\%)$ & Median $(01,03)$ & Mean \pm SD & Range \\
\hline Gestational age (weeks) & & $30.2[29,32.6]$ & $30.5 \pm 2.4$ & 26 to 34.2 \\
\hline Weight (kg) & & $1.1[0.9,1.38]$ & $1.14 \pm 0.3$ & 0.66 to 1.8 \\
\hline Gender (males) & $22(56.4)$ & & & \\
\hline Prenatal steroids & $16(41)$ & & & \\
\hline Surfactant administration & $22(56.4)$ & & & \\
\hline Early sepsis suspicion & $19(48.7)$ & & & \\
\hline PCA treatment & $4(10)$ & & & \\
\hline Days of hospital stay & & $30[20,48.5]$ & $38.95 \pm 28.7$ & 4 to 140 \\
\hline Mortality & $10(25.6)$ & & & \\
\hline PDA diagnosis within first $24 \mathrm{~h}$ & $14(35.9)$ & & & \\
\hline Pre-ductal PI at $24 \mathrm{~h}$ & & $1.2[0.85,1.53]$ & $1.36 \pm 0.9$ & 0.27 to 4.15 \\
\hline Post-ductal PI at $24 \mathrm{~h}$ & & $0.94[0.65,1.48]$ & $1.11 \pm 0.7$ & 0.32 to 3.35 \\
\hline$\Delta \mathrm{PI}$ at $24 \mathrm{~h}$ & & $0.24[-0.06,0.49]$ & $0.24 \pm 0.8$ & -2.12 to 2.76 \\
\hline DA diameter at $24 \mathrm{~h}(\mathrm{~mm})$ & 14 & $1.85[1.6,2.15]$ & $1.93 \pm 0.8$ & 0.3 to 4 \\
\hline LA: Ao ratio at $24 \mathrm{~h}$ & & $1.2[1.1,1.3]$ & $1.24 \pm 0.2$ & 0.9 to 2.2 \\
\hline Desc. aorta flow at $24 \mathrm{~h}(\mathrm{~m} / \mathrm{s})$ & & $0.78[0.56,0.9]$ & $0.74 \pm 0.3$ & 0.25 to 1.9 \\
\hline Aortic root at $24 \mathrm{~h}(\mathrm{~mm})$ & & $6.8[6.3,7.3]$ & $6.67 \pm 0.9$ & 6.3 to 7.3 \\
\hline Left atrium at $24 \mathrm{~h}(\mathrm{~mm})$ & & $8.4[7.1,9]$ & $8.4 \pm 1.4$ & 5.7 to 11.4 \\
\hline PDA diagnosis within the first $72 \mathrm{~h}$ & $9(23)$ & & & \\
\hline Pre-ductal PI at $72 \mathrm{~h}$ & & $1.31[0.95,1.84]$ & $1.44 \pm 0.7$ & 0.3 to 3.7 \\
\hline Post-ductal PI at $72 \mathrm{~h}$ & & $0.97[0.64,1.24]$ & $1.07 \pm 0.6$ & 0.4 to 3.2 \\
\hline$\Delta \mathrm{PI}$ at $72 \mathrm{~h}$ & & $0.27[0,0.63]$ & $0.27 \pm 0.7$ & -1.6 to 2.5 \\
\hline DA diameter at $72 \mathrm{~h}(\mathrm{~mm})$ & 9 & $2.7[1.2,3]$ & $2.22 \pm 1.3$ & 0.2 to 4 \\
\hline LA: Ao ratio at $72 \mathrm{~h}$ & & $1.2[1.1,1.3]$ & $1.23 \pm 0.2$ & 1 to 1.7 \\
\hline Desc. aortic flow at $72 \mathrm{~h}(\mathrm{~m} / \mathrm{s})$ & & $0.8[0.68,0.9]$ & $0.76 \pm 0.2$ & 0.2 to 1.3 \\
\hline Aortic root at $72 \mathrm{~h}(\mathrm{~mm})$ & & $6.8[6,7.4]$ & $6.7 \pm 1.2$ & 4 to 8.8 \\
\hline Left atrium at $72 \mathrm{~h}(\mathrm{~mm})$ & & $8.4[7.5,9.1]$ & $8.38 \pm 1.4$ & 4.7 to 11 \\
\hline
\end{tabular}

Q1, Q3: quartile 1, quartile 3 (interquartile range); SD: standard deviation; PDA: patent ductus arteriosus; PI: perfusion index; $\triangle \mathrm{PI}$ : perfusion index increase; desc.: descending; DA: ductus arteriosus; LA: left atrium; Ao: aortic valve.

characteristics. No cardiac malformations other than PDA were found. The diameter of the duct at $24 \mathrm{~h}$ in all 14 patients was $1.93 \pm 0.8 \mathrm{~mm}$ (range: $0.3-4 \mathrm{~mm}$ ) and in the nine patients with PDA, it was $2.22 \pm 1.3 \mathrm{~mm}$ (range: $0.2-4 \mathrm{~mm}$ ) at $72 \mathrm{~h}$. Ten patients (25.9\%) died during their stay at the NICU, with no death being attributed to cardiac causes. The causes were severe intraventricular hemorrhage, late neonatal sepsis, and septic shock.
In the bivariate analysis, which compares patients with and without a PDA diagnosis at 24 and $72 \mathrm{~h}$, as seen in tables 2 and 3 , no significant differences were found in baseline characteristics such as gestational age, weight, gender, prenatal steroid administration, surfactant administration or early sepsis suspicion, as well as in outcomes such as mortality and days of hospital stay $(p>0.05)$. 
Table 2. Comparison by PDA diagnosis at $24 \mathrm{~h}$

\begin{tabular}{|c|c|c|c|}
\hline \multirow[t]{2}{*}{ Variable } & \multicolumn{2}{|c|}{ PDA diagnosis at $24 \mathrm{~h}$} & \multirow[t]{2}{*}{ p-value } \\
\hline & No (25) & Yes (14) & \\
\hline $\begin{array}{l}\text { Gestational age (weeks) } \\
\text { Median }(01,03) \\
\text { Mean } \pm \text { SD }\end{array}$ & $\begin{array}{c}30[28,33.1] \\
30.4 \pm 2.69\end{array}$ & $\begin{array}{c}30.85[29,31.9] \\
30.6 \pm 1.91\end{array}$ & $0.77^{*}$ \\
\hline $\begin{array}{l}\text { Weight }(\mathrm{kg}) \\
\text { Median }(01,03) \\
\text { Mean } \pm \text { SD }\end{array}$ & $\begin{array}{c}1.21[0.91,1.46] \\
1.18 \pm 0.31\end{array}$ & $\begin{array}{c}1.07[0.83,1.25] \\
1.06 \pm 0.25\end{array}$ & $0.23^{*}$ \\
\hline Gender (males) & $15(60)$ & $7(50)$ & $0.54^{* *}$ \\
\hline Prenatal steroid admin. & $13(52)$ & $3(21)$ & $0.06^{\dagger}$ \\
\hline Surfactant admin. & $15(60)$ & $7(50)$ & $0.54^{* *}$ \\
\hline Suspected sepsis & $12(48)$ & $7(50)$ & $0.90^{* *}$ \\
\hline $\begin{array}{l}\text { Days of hospital stay } \\
\text { Median }(01,03) \\
\text { Mean } \pm \text { SD }\end{array}$ & $\begin{array}{l}29[20,48] \\
35.9 \pm 22.8\end{array}$ & $\begin{array}{c}32[25,51.5] \\
44.2 \pm 37.4\end{array}$ & $0.80^{\ddagger}$ \\
\hline Mortality & $6(24)$ & $4(28)$ & $1^{\dagger}$ \\
\hline $\begin{array}{l}\text { Pre-ductal PI at } 24 \mathrm{~h} \\
\text { Median }(01,03) \\
\text { Mean } \pm \text { SD }\end{array}$ & $\begin{array}{c}1.3[0.97,1.76] \\
1.4 \pm 0.73\end{array}$ & $\begin{array}{c}0.88[0.70,1.27] \\
1.3 \pm 1.06\end{array}$ & $0.12^{\ddagger}$ \\
\hline $\begin{array}{l}\text { Post-ductal PI at } 24 \mathrm{~h} \\
\text { Median }(01,03) \\
\text { Mean } \pm \text { SD }\end{array}$ & $\begin{array}{c}0.95[0.68,1.41] \\
1.08 \pm 0.59\end{array}$ & $\begin{array}{c}0.87[0.52,1.62] \\
1.17 \pm 0.86\end{array}$ & $0.88^{\ddagger}$ \\
\hline $\begin{array}{l}\Delta \mathrm{PI} \text { at } 24 \mathrm{~h} \\
\quad \text { Median }(01,03) \\
\text { Mean } \pm \mathrm{SD}\end{array}$ & $\begin{array}{c}0.22[0.06,0.58] \\
0.31 \pm 0.77\end{array}$ & $\begin{array}{c}0.03[-0.27,0.2] \\
0.12 \pm 0.92\end{array}$ & $0.09^{\ddagger}$ \\
\hline $\begin{array}{l}\text { Student's t-test. } \\
\text { *Chi-square test. } \\
\text { Fisher's exact test. } \\
\text { Mann-Whitney U-test. } \\
\text { 'DA: patent ductus arteriosus; } 0 \\
\text { ccrease. }\end{array}$ & & . & \\
\hline
\end{tabular}

Regarding the general objective, no statistically significant differences were found in $\triangle \mathrm{PI}$ in patients without and with PDA at $24 \mathrm{~h}(0.22[0.06-0.58]$ vs. 0.03 $[-0.27-0.2], p=0.09)$ or at $72 \mathrm{~h}(0.2[0-0.47]$ vs. 0.45 $[-0.37-0.76], p=0.47)$.

There were no differences found in isolated pre- and post-ductal PI at 24 and $72 \mathrm{~h}$ either (Tables 2 and 3 ).

Statistical associations were made between Pls and echocardiographic measurements, with a positive correlation with Spearman's rho between DAD and $\triangle \mathrm{PI}$ standing out ( $r: 0.78 ; 95 \% \mathrm{Cl}: 0.60-0.88 ; p=0.01$ ) in the nine patients with PDA a $72 \mathrm{~h}$ (Fig. 2). To assess for the veracity of this association, a power test was performed in the nine patients with that correlation, with the alpha-value being set at 0.05 and a beta-value of 0.7748061 being determined.

In the linear regression $(\mathrm{DAD} \sim \Delta \mathrm{PI})$, an $\mathrm{R}^{2}=0.66$, residual standard error $=0.82$, and statistical significance with $p=0.007$ were found. From this regression analysis, the following formula was obtained to predict DAD based on $\triangle \mathrm{PI} ; \mathrm{DAD}=1.31+(2.05 \times$ $\triangle \mathrm{PI})$. Based on this formula, clearing the $\triangle \mathrm{PI}$ and setting the necessary DAD for hemodynamic repercussion, $1.5 \mathrm{~mm}$, we might infer that when $\Delta \mathrm{PI}$ is $\geq 0.09$, the ductus arteriosus will have hemodynamic significance.

\section{Discussion}

The present study failed to demonstrate the usefulness of PI and its increase for HSPDA diagnosis in preterm newborns, since discriminating the presence or not of ductus arteriosus was not possible with this method, unlike reports in the literature, even with contradictory results, bearing in mind that the hypothesis was that, in the presence of HSPDA, there would be 
Table 3. Comparison by PDA diagnosis at $72 \mathrm{~h}$

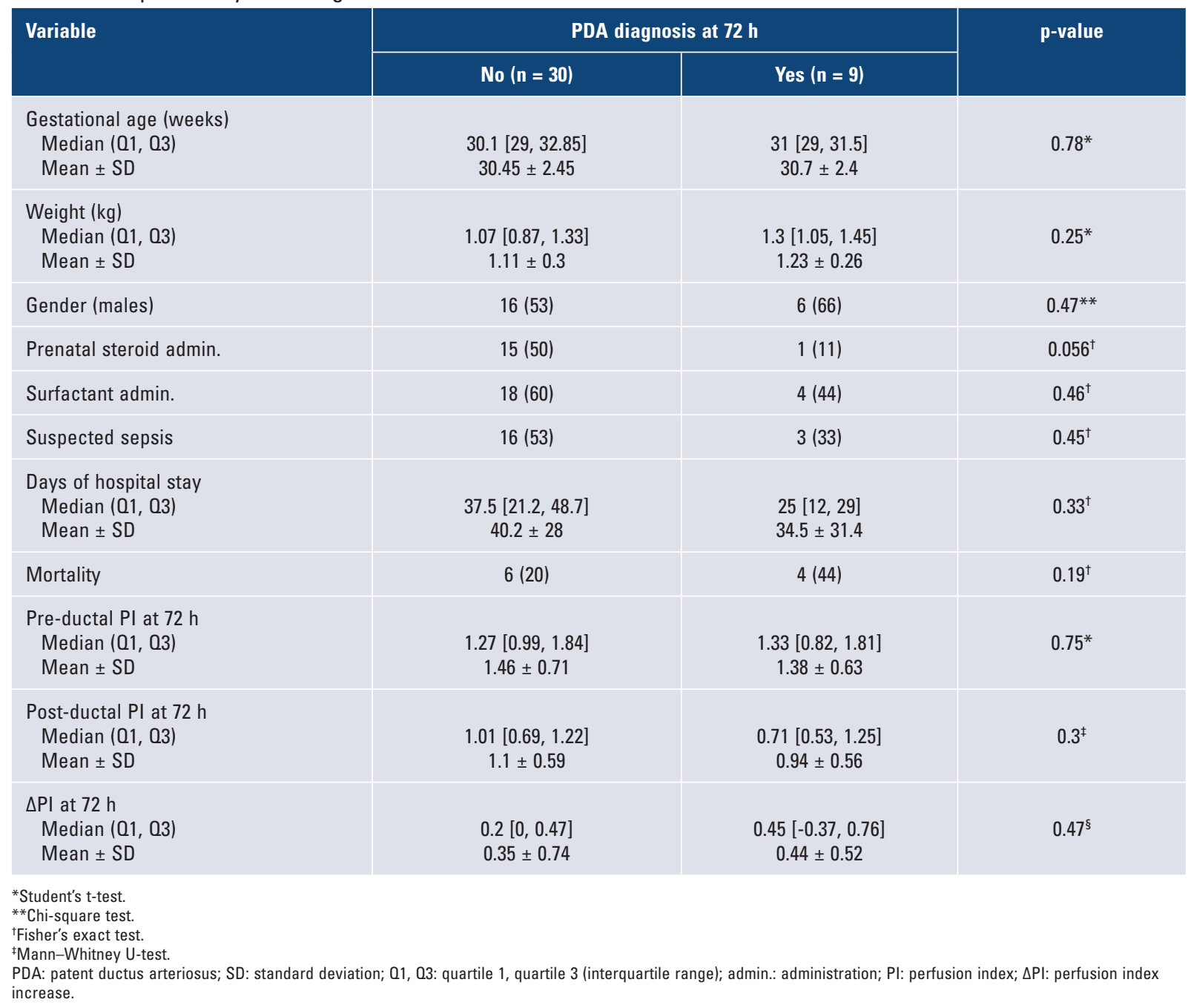

more blood flow stolen away towards pre-ductal perfusion, thus decreasing post-ductal perfusion and thereby making the increase larger. However, in our results at $24 \mathrm{~h}$, there was a trend towards $\Delta \mathrm{PI}$ being higher in patients without PDA. At $72 \mathrm{~h}$, there was a trend toward higher $\triangle \mathrm{PI}$ in patients with PDA: however, the difference was not statistically significant $(p=0.47)$.

After the PI was determined, finding the usefulness for this measurement in specific pathologies has been tried, predominantly in cardiac and circulatory conditions such as congenital structural heart diseases and hyperdynamic states such as severe sepsis ${ }^{12}$. However, the high variability in the devices that determine this parameter complicates the reproducibility of this type of studies. Unlike the results of our study, in 2013, Khositseth et al., with 30 patients and a $\Delta \mathrm{PI}$ cutoff point > 1.05 , were able to diagnose HSPDA with a sensitivity of $66.7 \%$ and $\mathrm{Sp}$ of $70 \%{ }^{14}$. On the other hand, Balla et al., with only 27 patients, established the cutoff point at 0.85 , with a sensitivity of $80 \%$ being obtained ${ }^{15}$. These results could not be replicated in our study. In 2017, Gómez-Pomar published an article about 31 patients under continuous monitoring and found greater usefulness in terms of variability than in $\Delta \mathrm{PI}$ crude value ${ }^{16}$. In our study, we found some similarity with the results obtained by Alderliesten, et al., who in 342 neonates reported a higher isolated post-ductal PI value in patients with HsPCA, with this being attributed to the hyperdynamic circulation that translates into increased pulse amplitude together with a component with decreasing general perfusion ${ }^{10}$. One of the most predominant issues for reflection is trying to understand when should $\Delta \mathrm{PI}$ be defined, i.e., should it be continuously measured and the change recorded? Should it be at a defined time? When there are signs of ductal hemodynamic repercussion present? 
During echocardiographic parameters subanalysis, a positive correlation was found between $D A D$ and $\triangle \mathrm{PI}$ in the nine patients who persisted with patent ductus arteriosus at $72 \mathrm{~h}$ of life, i.e., $\Delta \mathrm{PI}$ is directly proportional to $\mathrm{DAD}$, and, hence, to its hemodynamic repercussion. Using a linear regression analysis for the prediction of values, a formula was obtained that allows estimating the ductus diameter based on $\Delta \mathrm{Pl}$; this could be particularly useful for monitoring this subgroup of patients; i.e., in a patient diagnosed with PDA by echocardiogram at $72 \mathrm{~h}$ of life, continuous monitoring of pre- and post-ductal IP would allow estimating the diameter in real time using the $\Delta \mathrm{PI}$ and thereby determining HSPDAs severity and hemodynamic impact for its proper medical or surgical treatment.

\section{Conclusions}

$\mathrm{Pl}$ is a monitoring parameter that could be useful in certain pathologies, especially cardiac and hemodynamic; however, the high variability of its measurement between oximeters limits its reproducibility. It is necessary to unify the values obtained with the different systems and brands of devices that measure PI.

$\Delta \mathrm{PI}$ could be a useful tool in the monitoring of patients diagnosed with HSPDA by echocardiogram at $72 \mathrm{~h}$ of life, and, thus, for continuously and dynamically estimating the diameter of the ductus with its consequent hemodynamic impact on the newborn. Further studies are needed to reproduce this association and thus systematically using it within the neonatology rooms in this subgroup of patients.

\section{Funding sources}

The present investigation has not received specific support from public or commercial sector agencies or non-profit entities.

\section{Conflicts of interest}

The authors declare that they have no conflicts of interest relevant to this study.

\section{Ethical disclosures}

Protection of people and animals. The authors declare that no experiments were performed on humans or animals for this research.

Confidentiality of data. The authors declare that they have followed the protocols of their work center on the publication of patient data.

Right to privacy and informed consent. The authors declare that no patient data appear in this article.

\section{References}

1. Guía de Práctica Clínica Diagnóstico y Tratamiento de la Persistencia del Conducto Arterioso en niños, adolescentes y adultos [Internet]. México: Secretaría de Salud; 2010. Disponible en: http://www.cenetec.salud.gob. $\mathrm{mx} /$ descargas/gpc/CatalogoMaestro/380_GPC_PERSISTENCIA_DEL_ CONDUCTO_ARTERIOSO/GER_PERSISTENCIA_CONDUCTO_ARTERIOSO.pdf

2. Gillam-Krakauer M, Reese J. Diagnosis and management of patent ductus arteriosus. NeoReviews. 2018;19(7):e394-402.

3. Laughon MM, Simmons MA, Bose CL. Patency of the ductus arteriosus in the premature infant: is it pathologic? Should it be treated? Curr Opin Pediatr. 2004;16(2):146-51.

4. Coceani F, Baragatti B. Mechanisms for ductus arteriosus closure. Semin Perinatol. 2012;36(2):92-7.

5. Reese J, Laughon MM. The patent ductus arteriosus problem: Infants who still need treatment. J Pediatr. 2015;167(5):954-6.

6. Benitz WE. Treatment of persistent patent ductus arteriosus in preterm infants: time to accept the null hypothesis? J Perinatol. 2010;30(4):241-52.

7. Sehgal A, McNamara PJ. Does echocardiography facilitate determination of hemodynamic significance attributable to the ductus arteriosus? Eur J Pediatr. 2009;168(8):907-14.

8. Zonnenberg I, Waal $\mathrm{K}$ de. The definition of a haemodynamic significant duct in randomized controlled trials: a systematic literature review. Acta Paediatr. 2011:101(3):247-51.

9. Piasek CZ, Bel FV, Sola A. Perfusion index in newborn infants: a noninvasive tool for neonatal monitoring. Acta Paediatr. 2014;103(5):468-73.

10. Alderliesten T, Lemmers PMA, Baerts $W$, Groenendaal F, Bel $F$ van Perfusion index in preterm infants during the first 3 days of life: Reference values and relation with clinical variables. Neonatology. 2015;107(4):258-65.

11. Cresi F, Pelle E, Calabrese R, Costa L, Farinasso D, Silvestro L. Perfusion index variations in clinically and hemodynamically stable preterm newborns in the first week of life. Ital J Pediatr. 2010;36:6.

12. Felice CD, Latini G, Vacca P, Kopotic RJ. The pulse oximeter perfusion index as a predictor for high illness severity in neonates. Eur $\mathrm{J}$ Pediatr. 2002;161(10):561-2.

13. Vidal M, Ferragu F, Durand S, Baleine J, Batista-Novais AR, Cambonie G. Perfusion index and its dynamic changes in preterm neonates with patent ductus arteriosus. Acta Paediatr. 2013;102(4):373-8.

14. Khositseth $A$, Muangyod N, Nuntnarumit P. Perfusion index as a diagnostic tool for patent ductus arteriosus in preterm infants. Neonatology. 2013; 104(4):250-4.

15. Balla KC, John V, Rao PN S, Varghese K. Perfusion index-Bedside diagnosis of hemodynamically significant patent ductus arteriosus. J Trop Pediatr. 2016;62(4):263-8.

16. Gomez-Pomar E, Makhoul M, Westgate PM, Ibonia KT, Patwardhan A Giannone PJ, et al. Relationship between perfusion index and patent ductus arteriosus in preterm infants. Pediatr Res. 2017;81(5):775-9. 